\title{
Fístula colecistocutánea espontánea que imita un tumor osteocondral
}

\author{
Spontaneous collecystocutaneous fistula mimicking an osteochondral tumor
}

Eva Antonaya Rubia ${ }^{1}$, Inés Capitán del Río ${ }^{1}$, Moisés El Adel Del Fresno ${ }^{1}$

La fístula colecistocutánea espontánea es una complicación infrecuente de la patología litiásica biliar, con menos de 100 casos descritos. Aunque su etiología es diversa, la más frecuente es la obstrucción no tratada del árbol biliar. Actualmente, en nuestro medio, el tratamiento precoz de la patología litiásica biliar evita la cronificación de estos procesos, aunque siempre se deben de tener en cuenta a la hora de realizar diagnostico diferencial completo en pacientes con síntomas a nivel de hipocondrio derecho.

Presentamos el caso de una mujer de 38 años de origen marroquí, residente en España desde hace pocos meses. Consultó por primera vez con su médico de atención primaria por autopalpación de masa dolorosa a nivel de parrilla costal derecha, sospechándose inicialmente tumor de partes blandas dependiente de arco costal por imágenes de ECO y TC. Se completó estudio con RM, mostrando la presencia de colecistitis crónica con trayecto fistuloso hacia piel, colelitiasis y múltiples litiasis intracísticas y coledocianas. Previamente a la inclusión quirúrgica, la paciente desarrolló una apertura espontánea del orificio fistuloso cutáneo con supuración purulenta y exteriorización de litiasis a través del mismo. Se decidió ingreso para antibioterapia intravenosa, realización de CPRE y posterior colecistectomía laparoscópica.

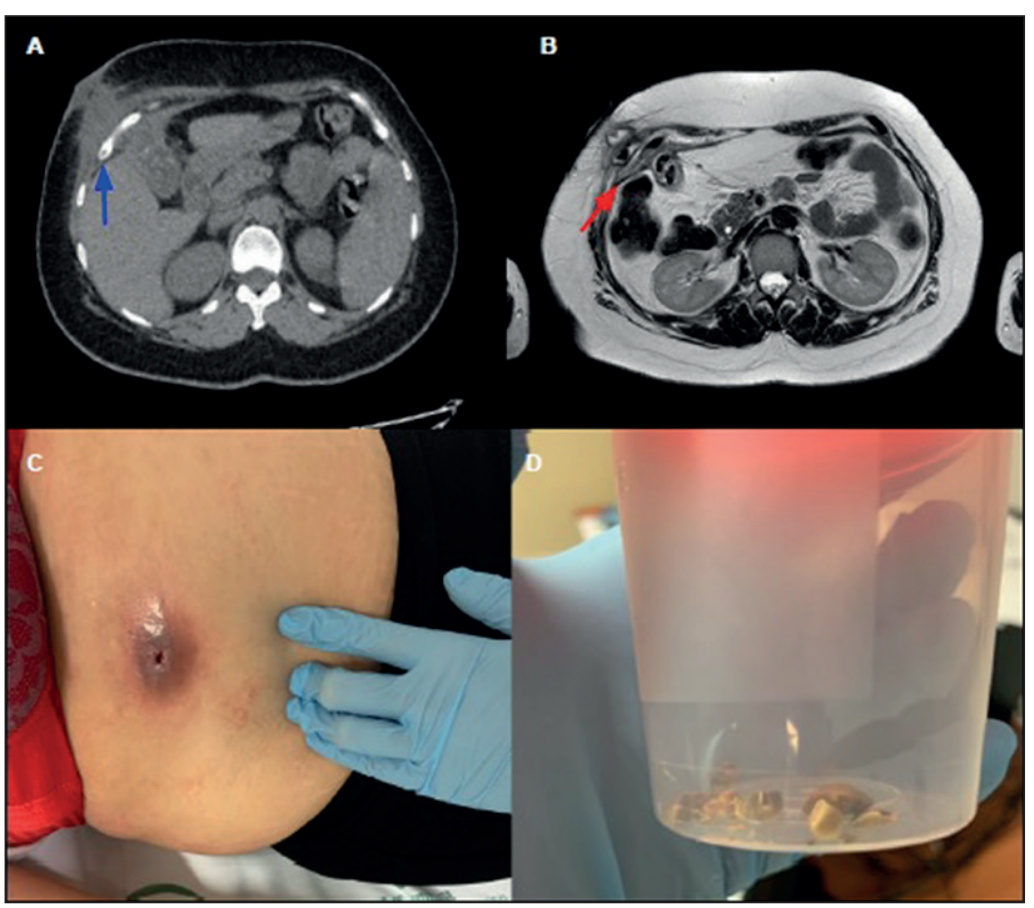

Figura 1. A: corte transversal de TC que muestra tumoración de partes blandas (señalada con flecha azul) junto a arco costal derecho sugerente de tumor osteocondral. B: imagen de RMN realizada posteriormente en la que se describe trayecto fistuloso desde la vesícula biliar hacia la piel (señalada con flecha roja), con afectación de partes blandas contiguas. Las imágenes $\mathbf{C}$ y D muestran el orificio fistuloso externo cutáneo y las litiasis extraídas durante la exploración física.
'Departamento de Cirugía General y del Aparato Digestivo. Hospital Universitario de Jaén, España. Recepción 2021-04-19, aceptado 2021-04-24

Correspondencia a: Dra. Inés Capitán del Río ines ml@hotmail.com 


\section{Responsabilidades éticas}

Protección de personas y animales. Los autores declaran que para esta investigación no se han realizado experimentos en seres humanos ni en animales.

Confidencialidad de los datos. Los autores declaran que en este artículo no aparecen datos de pacientes.

Conflictos de interés: no hay.

Autorización de publicación: Se obtuvo el consentimiento informado por escrito de la paciente previo a la revisión de sus datos.

\section{Bibliografia}

1. Santos-Seoane S, Díaz-Fernández V, Arenas-García V. Fístula colecistocutánea. Rev Esp Enferm Dig. 2019:111:407-8.

2. Rinzivillo NMA, Danna R, Leanza
V, Lodato M, Marchese S, Basile F, et al. Case Report: Spontaneous cholecystocutaneous fistula, a rare cholethiasis complication [version 1; referees: 3 approved] F1000Research 2017, 6:1768. Published online 2017 Sep
27. doi: 10.12688/f1000research.12235.1.

3. Guardado-Bermúdez F, Aguilar Jaimesa A, Ardisson-Zamora FJ, Guerrero-Silva LA, Villanueva-Rodríguez E, Gómezde Leija NA. Fístula colecistocutánea espontánea. Cir Cir. 2015;83:61-4. 